\title{
Luteal oxytocin and monoestry in the roe deer Capreolus capreolus
}

\author{
A. P. F. Flint ${ }^{1}$, A. Krzywinski ${ }^{2}$, A. J. Sempéré ${ }^{3}$, R. $_{\text {Mauget }}{ }^{3}$ and \\ A. Lacroix ${ }^{3}$ \\ ${ }^{I}$ Department of Physiology and Environmental Science, University of Nottingham, Sutton Bonington, \\ Loughborough, LE12 5RD, UK; ${ }^{2}$ Ferma Jeleniowatych PAN, 11-730 Kosewo, Poland; and ${ }^{3}$ Centre \\ d'Etudes Biologiques de Chizé (CNRS), 79360 Villiers en Bois, France
}

\begin{abstract}
The relationship between the corpus luteum and the uterus in terms of the secretion of oxytocin and $\mathrm{PGF}_{2 \alpha}$ was investigated in free-living and captive roe deer Capreolus capreolus. During the breeding season the corpus luteum contained oxytocin and oxytocinneurophysin mRNA, and secreted oxytocin in response to administration of the PGF $2 a$ analogue cloprostenol. The oxytocin receptor was present in the uterus during the breeding season and during delayed implantation; however, in contrast to the situation observed in other ruminants in which it has been studied, administered oxytocin did not stimulate uterine secretion of $\mathrm{PGF}_{2 \alpha}$. Trophoblast interferon was undetectable at any stage of conceptus development. The absence of the mechanism underlying episodic uterine secretion of $\mathrm{PGF}_{2 \alpha}$ during luteolysis, which may account for the monoestry of roe deer, is consistent with the previously observed luteolytic effect of the $\mathrm{PGF}_{2 \alpha}$ analogue.
\end{abstract}

\section{Introduction}

Mating in roe deer Capreolus capreolus takes place in July or August and is followed by a period of obligatory delayed implantation lasting until January; birth occurs in the following May or June (Bischoff, 1854; Short and Hay, 1966; Aitken, 1981). The roe deer is the only artiodactyl known to use delayed implantation as a reproductive strategy. One prerequisite for the establishment of delayed implantation in this species appears to be the monoestry of the doe. In captive roe deer does held during the breeding season in the absence of a buck, circulating concentrations of progesterone show that a corpus luteum formed after the spontaneous ovulation in July or August continues to secrete progesterone until March (Hoffmann et al., 1978; Schams et al., 1980; Sempéré et al., 1992a). In pregnant does the profile of circulating progesterone between August and December is similar, but thereafter concentrations rise between January and March before declining between March and May. There is no difference between the mass of the corpus luteum in does carrying blastocysts and in those that are not pregnant.

These characteristics suggest that the corpus luteum formed after mating is maintained by a process distinct from the blockade of cyclic corpus luteum regression by a product of the developing conceptus (the phenomenon known as maternal recognition of pregnancy, which occurs in cervids with seasonal polyoestry; Short, 1969). Rather, it seems that monoestry in the roe deer represents a genetic adaptation rendering maternal recognition of pregnancy redundant. Schams et al. (1980) proposed that this may reflect the fact that the blastocyst enters and remains in diapause in too underdeveloped a

Received 13 December 1993. form to produce the signal required to block luteal regression in polyoestrous cervids.

In those members of the Cervidae and Bovidae in which it has been studied in detail, the cyclic luteal regression that is characteristic of the polyoestrous condition involves episodes of secretion of the luteolytic compound $\mathrm{PGF}_{2 \alpha}$ by the uterus (for cervids, see Asher et al., 1988). It has been proposed that these episodes arise through the operation of a positive feedback loop involving oxytocin secreted by the corpus luteum (Flint et al., 1991); oxytocin stimulates uterine $\mathrm{PGF}_{2 \alpha}$ secretion and $\mathrm{PGF}_{2 \alpha}$ in turn stimulates the release of luteal oxytocin (Flint et al., 1990; Silvia et al., 1991). One explanation for the monoestry of roe deer may be the lack of one or more of the components of this positive feedback loop. This study investigated the relationship between the corpus luteum and the uterus in terms of the interactions between oxytocin and $\mathrm{PGF}_{2 \alpha}$ secreted by these organs. The data are interpreted in the context of the absence of cyclic luteal regression in this species.

\section{Materials and Methods}

\section{Animals}

Tissue samples and uterine flushings were obtained within $1 \mathrm{~h}$ of death from 27 does culled by rangers of the Forestry Commission in Thetford Forest, Norfolk, UK, during the periods 29 November 1989 to 4 January 1990 and 6 December 1990 to 10 January 1991. Only those animals that had ovulated (as judged by the presence of corpora lutea; $N=22$ ) are described here, and in none was a conceptus implanted. Ovarian and uterine tissue samples were also obtained from three does shot (for other purposes) in the Mazuria region of 
northeastern Poland on 10 and 11 August 1991; the licence from the Ministry of Nature Conservation and Forestry, Warsaw, under which these animals were taken, stipulated that any dependent young should be identified and either killed or hand-reared, and this requirement was complied with.

Jugular venous blood samples were obtained by venepuncture from nine captive does at the Centre d'Etudes Biologiques de Chizé (CNRS), France. For administration of either prostaglandin (325 $\mu \mathrm{g}$ cloprostenol i.m.) or oxytocin ( $1 \mu \mathrm{g}$ i.v.) and for subsequent removal of blood samples, identified does were immobilized, using routine techniques, in a race between open and wooded areas of their enclosure, as described by Sempéré et al. (1992a). Four adult females were also maintained in light-proof rooms and were exposed to an artificial photoperiod of long days ( $16 \mathrm{~h}$ light: $8 \mathrm{~h}$ dark) over a period of a year from the summer solstice (21 June). All animals were lightly sedated by injecting $0.6 \mathrm{mg}$ xylazine hydrochloride $\mathrm{kg}^{-1}$ i.m. (Rompun:Bayer, Leuerkusen) during collection of blood samples, which lasted no longer than $1 \mathrm{~h}$ in any case. Does were treated at oestrus, or at defined stages after oestrus, following induction of oestrus by $325 \mu \mathrm{g}$ cloprostenol i.m. (Sempéré et al., 1992a). Analysis of plasma progesterone concentrations confirmed the presence or absence of a corpus luteum, as appropriate: the concentration of progesterone was in the ranges $7.9-9.81,1.59-2.61$ and $1.18-1.37 \mathrm{nmol} \mathrm{l}^{-1}$ before, and $24 \mathrm{~h}$ and $48 \mathrm{~h}$ after cloprostenol treatment, respectively.

\section{Extraction of tissues}

All corpora lutea were treated separately. For extraction of oxytocin, weighed samples of luteal tissue were homogenized

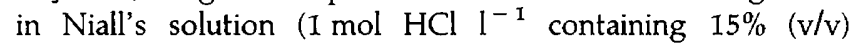
trifluoracetic acid, $5 \%(\mathrm{v} / \mathrm{v})$ formic acid and $1 \% \mathrm{NaCl}$ ). Homogenates were centrifuged at $10000 \mathrm{~g}$ for $20 \mathrm{~min}$ at $4^{\circ} \mathrm{C}$ and supernatants stored at $-70^{\circ} \mathrm{C}$ or below before assay. RNA was extracted from the luteal tissue by homogenization in $1 \mathrm{ml}$ sterile sodium citrate $\left(25 \mathrm{mmol} \mathrm{l}^{-1}, \mathrm{pH} 8.0\right)$, containing $4 \mathrm{~mol}$ guanidine isothiocyanate $1^{-1}, 0.1$ mol mercaptoethanol $1^{-1}$ and $0.5 \%(\mathrm{w} / \mathrm{v})$ Sarkosyl. For measurement of oxytocin receptors, uterine tissues (chopped caruncular and intercaruncular tissue collected separately) were washed in $0.9 \% \mathrm{NaCl}(\mathrm{w} / \mathrm{v})$ containing $1 \mathrm{mmol}$ EDTA $1^{-1}$ before homogenization in $25 \mathrm{mmol}$ Tris- $\mathrm{HCl} \mathrm{l}^{-1}$ containing $0.25 \mathrm{~mol}$ sucrose $\mathrm{l}^{-1}$ and 1 mol EDTA $~^{-1}$ (Sheldrick and Flint, 1985). In all cases, tissue samples were frozen upon collection and before extraction in the homogenization buffer or the washing buffer; in Thetford Forest this was achieved on dry ice; in Poland liquid nitrogen was used. Subsequent extractions were carried out using the methods of Chomczynski and Sacchi (1987) for RNA, and those of Sheldrick and Flint (1985) for oxytocin receptors. Plasma samples prepared by addition of heparin were centrifuged at $2000 \mathrm{~g}$ for $15 \mathrm{~min}$ immediately after collection and stored at $-20^{\circ} \mathrm{C}$; they were transported, where necessary, on dry ice.

\section{Oxytocin radioimmunoassay}

Oxytocin was concentrated from plasma or tissue extracts by adsorption to, and elution from, $C_{18}$ Sep-Paks (Waters
Associates, Milford, MA; Hooper et al., 1986). The hormone was subsequently assayed as described by Sheldrick and Flint (1981, 1986), using ${ }^{125}$ I-labelled oxytocin and an antibody raised in sheep; bound and free label were separated using polyethylene glycol. The assay had previously been validated for cervid plasma (Flint et al., 1991). The extraction efficiency was $84 \%$, and values were corrected for losses at this stage. The assay sensitivity was $0.9 \mathrm{fmol}$ per tube and the intra-assay coefficient of variation was $10.3 \%$.

\section{3,14-Dihydro-15-ketoprostaglandin $F_{2 a}$ (PGFM) radioimmunoassay}

PGFM was assayed in diethyl ether extracts of plasma as described by Kaker et al. (1984) following validation for deer plasma. Antibody crossreactions were performed as described by Kaker et al. (1984); extraction efficiencies were greater than $80 \%$ and assay blanks were in the range $116-161 \mathrm{pmol}^{-1}$ (charcoal-stripped plasma). The intra-assay coefficient of variation was $6.2 \%$ (quality control at $706 \mathrm{pmol} \mathrm{I}^{-1}$ ).

\section{Oxytocin receptor assay}

Oxytocin receptor binding was measured in uterine extracts prepared in buffered sucrose-EDTA by incubating microsomal fractions with $5 \mathrm{nmol}\left[{ }^{3} \mathrm{H}\right]$ oxytocin $1^{-1}$ (Amersham International, Amersham) with and without unlabelled oxytocin to determine nonspecific binding, as described by Sheldrick and Flint (1985). When this method was validated for cervid tissues by altering the incubation times and the temperature, the incubation buffer cation and the concentration of this cation, and receptor fraction concentration, as described by Sheldrick and Flint (1985) for ovine tissue, optimal conditions were found to be identical to those used for sheep.

\section{Northern blotting}

RNA was purified from guanidine isothiocyanate extracts by partitioning it between phenol and chloroform, precipitating it in ethanol and storing it in water. After spectrophotometric determination of RNA concentrations, $10 \mu \mathrm{g}$ was loaded onto $1 \%(\mathrm{w} / \mathrm{v})$ agarose gels containing formamide. After the gels had been run they were blotted onto Hybond $N$ nylon membranes (Amersham International) using $10 \times \mathrm{SSC}(1 \times \mathrm{SSC}=0.15 \mathrm{~mol}$ $\mathrm{NaCl} \mathrm{l}^{-1}, 0.015$ mol sodium citrate $\left.\mathrm{l}^{-1}\right)$. Membranes were subsequently probed at $65^{\circ} \mathrm{C}$ in $50 \mathrm{mmol}$ Tris- $\mathrm{HCl} \mathrm{I} \mathrm{I}^{-1}$ (pH 7.6) containing $1 \mathrm{~mol} \mathrm{NaCl} \mathrm{I}{ }^{-1}, 6 \%(\mathrm{w} / \mathrm{v})$ polyethylene glycol, $10 \times$ Denhardt's solution [100 $\times$ Denhardt's $=2 \%(\mathrm{w} / \mathrm{v})$ BSA, $2 \%(\mathrm{w} / \mathrm{v})$ Ficoll 400 and $2 \%(\mathrm{w} / \mathrm{v})$ polyvinylpyrrolidone], $0.1 \%(w / v)$ sodium pyrophosphate and $100 \mu \mathrm{g}$ denatured salmon sperm DNA ml-1. The membranes were washed at $65^{\circ} \mathrm{C}$ in $6 \times$ SSC containing $0.1 \%(w / v)$ SDS. The probe used was a $172 \mathrm{bp}$ cDNA derived from the $3^{\prime}$ end of the bovine oxytocin-neurophysin prohormone mRNA (kindly supplied by $G$. Schütz, Institut für Zellbiologie und Tumorbiologie, Deutsches Krebsforschungszentrum, Heidelberg; see Jones and Flint, 1988), which was labelled with ${ }^{32} \mathrm{P}$ using the multiprime method (Amersham International). After hybridization, the blots were exposed to film using routine procedures. 


\section{Interferon assay}

The concentration of interferon was measured by the cytopathic effect inhibition assay described by Meager (1987). Briefly, monolayer cultures of $2.5 \times 10^{4}$ Madin Darby bovine kidney cells were established in 96-well plates on day 1 in the presence of bovine recombinant interferon $\alpha_{1}$ standards $\left(0-13.34 \mathrm{ng} \mathrm{ml}^{-1} ; 1.57 \mathrm{iu} \mathrm{ng}^{-1}\right)$ or unknown standards. On day 2 , the lowest concentration of Semliki Forest virus required to cause death of all the cells was added to each well. On day 3 the monolayers were rinsed, washed and stained, and the number of cells was determined using a multiwell plate reader. Cells plus virus (no interferon controls) and cells alone (no virus controls) were included on each plate, and the midpoint between these values was used to calculate the concentrations of interferon in dilutions of the unknown standards. This assay is sensitive to bovine, cervid and porcine trophoblast interferons (limit of detection was $10-50 \mathrm{iu} \mathrm{ml}{ }^{-1}$ test solution).

\section{Statistical analyses}

Values are means \pm SEM; numbers of animals are indicated by $N$, numbers of samples by $n$. All means, SE values and statistical tests were based on the number of animals. Both parametric and nonparametric statistical tests were used, as indicated in the text. In the case of the secretion of oxytocin in response to cloprostenol, the data were not normally distributed (Kolmogorov-Smirnoff test); however, after the data had been log-transformed they passed this test $(P>0.2)$ and a paired $t$ test was then applied.

\section{Results}

Of the 22 postovulatory animals examined in Thetford Forest between late November and early January, ten had one corpus luteum, II had two corpora lutea and one had three. Blastocysts were identified in the uterine flushings from 16 of these does, and of the 12 animals displaying multiple ovulations, more than one blastocyst was found in nine cases. Elongated blastocysts were present in four animals (on 21 and 27 December) and an expanded blastocyst in one (10 January). Where multiple ovulations had occurred, the corpora lutea were in the same ovary in $75 \%$ of animals. In the 13 animals in which ovulation was confined to one ovary and from which a blastocyst was flushed, a conceptus was in the uterine horn ipsilateral to the ovary bearing the corpora lutea in only four cases. The mean ( \pm SEM) wet mass of corpora lutea in does from Thetford was $92.0 \pm 5.6 \mathrm{mg}(n=35$ samples; $N=22$ animals) and the mean wet mass of the uterus in these animals was $18 \pm 1.1 \mathrm{~g}(\mathrm{~N}=22$ animals).

\section{Concentration of luteal oxytocin and of uterine oxytocin receptors}

The concentration of oxytocin in luteal tissue, and of oxytocin receptors in intercaruncular uterine tissue was $56 \pm 9.9 \mathrm{pmol} \mathrm{g}^{-1}(\mathrm{~N}=22$ animals $)$ and $80.0 \pm 16.9 \mathrm{fmol}$ $\mathrm{mg}^{-1}$ protein $(N=22$ animals), respectively, in postovulatory animals sampled in Thetford Forest between November and

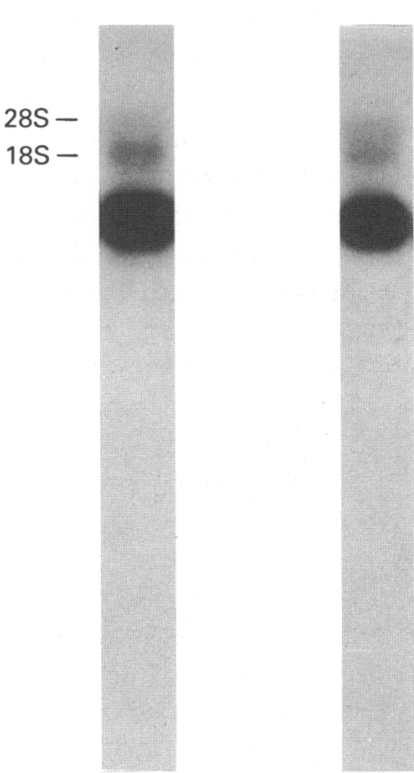

Fig. 1. Representative northern biots of RNA from corpora lutea of roe deer and sheep. (a) RNA from a single corpus luteum obtained from a roe deer in August (1.3 $\mu \mathrm{g}$ RNA loaded on the gel). (b) RNA from a single corpus luteum from a sheep (positive control; $5.1 \mu \mathrm{g}$ RNA loaded). The positions of $18 \mathrm{~S}$ and $28 \mathrm{~S}$ RNA are indicated.

January. The concentration of luteal oxytocin was unrelated to the number of ovulations, the time of year or the ability to flush a blastocyst from the uterus; the concentration of oxytocin receptors in the uterus tended to rise towards the end of the sampling period but was not related to the other parameters.

In tissues collected in Poland during the breeding season, the mean masses of the corpora lutea and uteri were $70 \pm 15 \mathrm{mg}$ ( $n=$ five corpora lutea) and $24 \pm 4.9 \mathrm{~g}(N=$ three animals in each case). The concentration of oxytocin in luteal tissue, and of oxytocin receptors in intercaruncular endometrium were $199 \pm 60 \mathrm{pmol} \mathrm{g}^{-1}$ and $64 \pm 14 \mathrm{fmol} \mathrm{mg}^{-1}$ protein, respectively, in these does $(N=3)$; the highest concentrations of oxytocin observed (in two corpora lutea from a single doe on 10 August) were 393 and $404 \mathrm{pmol} \mathrm{g}^{-1}$ tissue. The mean luteal oxytocin concentration in August, therefore, appeared to exceed the concentration in samples obtained between November and January; however, this difference was not statistically significant (Mann-Whitney Rank Sum test, $P=0.126$ )

\section{Oxytocin-neurophysin $m R N A$ in corpora lutea}

The presence of oxytocin in corpora lutea obtained during August was confirmed by northern blotting luteal extracts (Fig. 1); simultaneous analysis of RNA from sheep corpora lutea, which are known to contain oxytocin-neurophysin mRNA (Jones and Flint, 1988) showed that the mRNA from roe deer was indistinguishable in size from that of the sheep. 

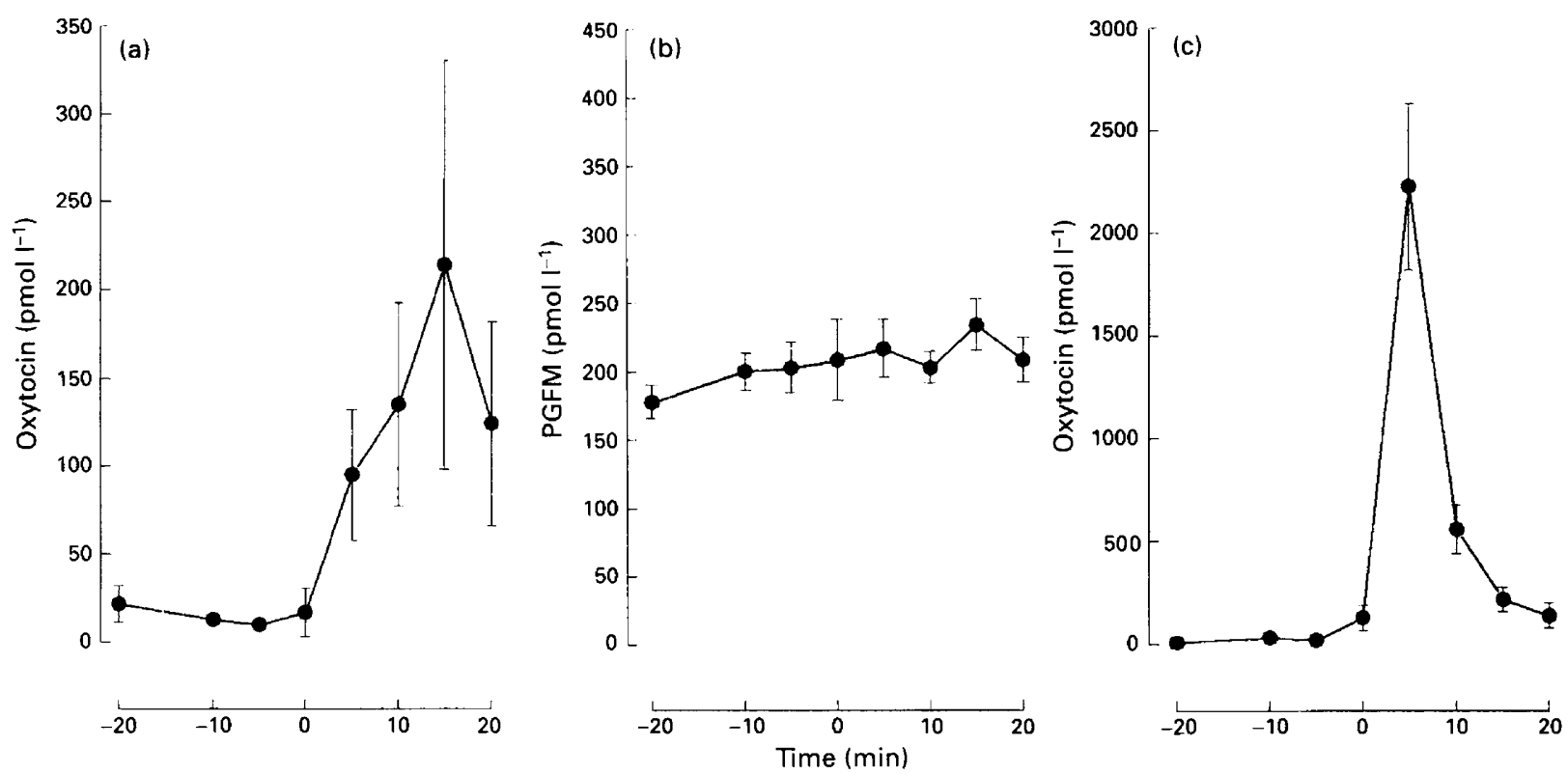

Fig. 2. (a) Concentrations of oxytocin in jugular venous plasma of roe deer does $(n=3)$ before and after administration of cloprostenol (325 $\mu \mathrm{g}$ i.m.) on day 10 after ovulation during the breeding season, in August. (b) Concentrations of 13,14-dihydro-15-keto prostaglandin $\mathrm{F}_{2 \alpha}(\mathrm{PGFM})$ in jugular venous plasma of three does before and after administration of oxytocin ( $1 \mu \mathrm{g}$ i.v.) on day 3 after inducing oestrus with cloprostenol (administered on day 0) during the breeding season, in August. (c) Concentrations of oxytocin achieved in three does before and after administration of oxytocin ( $1 \mu \mathrm{g}$ i.v.) 3 days after inducing oestrus with cloprostenol (administered on day 0 ) during the breeding season, in August. Vertical bars indicate SE (based on the number of animals).

\section{Secretion of oxytocin in response to $P G F_{2 \alpha}$ analogue}

The mean concentrations of oxytocin in jugular venous plasma from three does on day 10 after oestrus during the breeding season (August) are shown (Fig. 2a). The mean plasma concentration before the administration of the $\mathrm{PGF}_{2 \alpha}$ analogue cloprostenol was $15 \pm 3.2 \mathrm{pmol}^{-1}$ (nine samples from three animals); in each case the administration of cloprostenol raised the circulating oxytocin concentration within $5 \mathrm{~min}$ of treatment. Peak concentrations reached in the three animals were $86 \mathrm{pmoll}^{-1}$ (at $5 \mathrm{~min}$ after treatment) and 113 and $446 \mathrm{pmol} \mathrm{l}^{-1}$ (15 min after treatment), respectively; the mean concentration between 5 and $20 \mathrm{~min}$ after treatment was $142 \pm 66 \mathrm{pmol}^{-1}$ (12 samples from three animals; paired $t$ test following $\log$ transformation, $P=0.019 ; 2$ d.f.).

To investigate whether cloprostenol stimulated oxytocin secretion at other times of the year, or in does in which ovulation had been delayed by changes in photoperiod, further experiments were carried out during the period when blastocysts are normally quiescent. In contrast to the effect observed in August, cloprostenol administered on 29 October caused a relatively small rise (by a factor of three) in the circulating concentration of oxytocin in two of four-does kept on long days from the summer solstice, and had no effect on the remaining pair or in control animals kept under the natural photoperiod (data not shown; $P>0.1$ in both cases). In all cases, measurement of the circulating progesterone concentration confirmed that ovulation had occurred. Circulating concentrations of oxytocin before treatment in animals under control or experimental photoperiods $\left(62 \pm 6.4 \mathrm{pmol} \mathrm{I}^{-1}\right.$; $n=21$ samples from seven animals) were higher than pretreat- ment concentrations during the breeding season ( $t$ test, $P<0.002 ; 8$ d.f.).

\section{Secretion of prostaglandin in response to oxytocin}

There was no detectable increase in the circulating concentration of PGFM following administration of oxytocin 3 days after treatment with cloprostenol, when oxytocin was administered during the breeding season (Fig. 2b) or in late October in animals maintained on long days (data not shown). When the oxytocin concentration was measured following oxytocin administration, to confirm appropriate treatment, the concentration had increased from a mean pretreatment concentration of $21.0 \pm 2.7 \mathrm{pmol} \mathrm{l}^{-1}$ ( $n=9$ samples from three animals) to a peak concentration after oxytocin administration of $2228 \pm 405 \mathrm{pmol}^{-1}$ ( $N=3$ animals; Fig. $\left.2 \mathrm{c}\right)$ and remained high for $20 \mathrm{~min}$.

\section{Interferon in uterine flushings during delayed implantation}

Interferon was not detectable in any sample obtained between August and January, including five samples obtained after the blastocyst had elongated.

\section{Discussion}

Two principal differences between the roe deer and other ruminants arise from the present study. Firstly administration of oxytocin to animals during oestrus failed to elicit the dramatic increase in uterine secretion of $\mathrm{PGF}_{2 a}$ that is usually 
observed in polyoestrous ruminants late in the cycle or at oestrus; this was the case both during the natural breeding season and in does held on a long-day photoperiod to extend the breeding season. This represents a breakdown in the positive feedback loop involving $\mathrm{PGF}_{2 \alpha}$ and oxytocin to promote episodic $\mathrm{PGF}_{2 \alpha}$ secretion at luteolysis and, if confirmed, this observation would explain the absence of luteolysis in the roe deer. This finding is consistent with the observation that an administered $\mathrm{PGF}_{2 \alpha}$ analogue is luteolytic between October and March (Sempéré et al., 1992a), which suggests that a failure of luteolysis might be reversed by appropriate hormone replacement therapy.

Second, interferon was not detected in uterine flushings of roe does at any stage before or after implantation of the blastocyst, although a range of stages of blastocyst development was tested. Secretion of interferon by the trophoblast has been implicated in the maintenance of luteal function in polyoestrous ruminants, blocking uterine $\mathrm{PGF}_{2 \alpha}$ secretion by inhibiting the expression of the gene encoding the oxytocin receptor (Flint et al., 1992). Absence of trophoblast interferon is consistent with the absence of a mechanism for producing episodes of $\mathrm{PGF}_{2 \alpha}$ secretion, since without luteolysis a mechanism for maternal recognition of pregnancy at the blastocyst stage is redundant. Absence of trophoblast interferon secretion during delayed implantation may reflect the early stage at which the blastocyst becomes delayed (Schams et al., 1980): in those ruminants in which it has been studied in detail the secretion of interferon from the trophoblast is a characteristic of the elongating, or expanded, blastocyst and is absent or difficult to detect in small, spherical blastocysts comparable in size ( $1 \mathrm{~mm}$ diameter) to those of the roe deer at the onset of delayed implantation.

The spontaneous ovulation occurring in roe deer in July or August is preceded by a brief rise in the circulating concentration of progesterone, which is similar to the preoestrus short luteal cycle of domestic bovids (Hoffmann et al., 1978; Schams et al., 1980; Sempéré et al., 1992a). The cause of the early regression of this short-lived corpus luteum is unknown; but the fact that regression occurs indicates that a luteolytic mechanism exists at this stage. In sheep and cattle the premature regression of corpora lutea in short luteal cycles is associated with the secretion of uterine $\mathrm{PGF}_{2 \alpha^{\prime}}$ which is possibly driven by oxytocin via the endometrial oxytocin receptor (Hunter et al., 1989). Uterine concentrations of the oxytocin receptor are high in anoestrous or immature roe deer, as in anoestrous sheep (approximately $300 \mathrm{fmol} \mathrm{mg}^{-1}$ protein; A. P. F. Flint, unpublished); it is therefore possible that regression of short-cycle corpora lutea in roe deer reflects anomalous oxytocin-induced secretion of uterine prostaglandin in a manner uncharacteristic of the fully functional corpora lutea formed later in the breeding season.

The presence of oxytocin and of oxytocin-neurophysin mRNA in corpora lutea of roe deer indicates that these organs synthesize the peptide. However, the highest concentration of oxytocin observed in luteal tissue (a mean value of $400 \mathrm{pmol}$ $\mathrm{g}^{-1}$ wet mass) was low compared with that in corpora lutea of red deer (up to $66 \mathrm{nmol} \mathrm{g}^{-1}$, Flint et al., 1991; mean, $15 \pm 3 \mathrm{nmol} \mathrm{g}^{-1}, N=25$ animals; A. P. F. Flint and S. D. Albon, unpublished). The corpora lutea of roe deer (approximately $100 \mathrm{mg}$ wet mass) are smaller than those of red deer (approximately $350 \mathrm{mg}$ ), so despite the relatively low body mass of the roe compared with that of the red deer (approximately 20 versus $150 \mathrm{~kg}$ ), the total amount of luteal oxytocin $\mathrm{kg}^{-1}$ body mass is lower in the doe than in the hind (4 versus $35 \mathrm{pmol} \mathrm{kg}^{-1}$ ). This is inconsistent with the higher peripheral plasma concentrations of oxytocin that are reached following prostaglandin administration in the roe compared with red deer or Père David's deer, Elaphurus davidianus (214 versus 97 and 153 pmol $^{-1}$, respectively; data of the present study and Flint et al., 1991). However, it should be noted that the relatively low oxytocin concentrations in the corpora lutea of the roe deer observed here may reflect the age of the organ following ovulation. In other ruminants (sheep, cattle and red deer Sheldrick and Flint, 1983; A. P. F. Flint and S. D. Albon, unpublished) luteal concentrations of oxytocin decline to low concentrations about two weeks after ovulation. As the corpora lutea of roe deer do not undergo luteolysis for a prolonged period, and the time of ovulation was not determined in the three free-living does studied here, it is possible that the samples were obtained sufficiently long after ovulation for concentrations already to have declined. Oxytocin clearance rates may also contribute to the interspecies differences observed. The higher circulating concentrations of oxytocin observed in October relative to those present in August may reflect secretion by a source other than the corpora lutea.

Support for the hypothesis tested here that monoestry in the roe deer reflects a lack of oxytocin-activated endometrial PGF $2 \alpha$ synthesis depends upon a negative observation; that is, that oxytocin administration failed to elicit $\mathrm{PGF}_{2 \alpha}$ secretion, as indicated by the absence of an effect on circulating concentrations of PGFM. There are a number of less significant explanations for this result but many can be refuted: first, administered oxytocin entered the circulation, as shown by measuring plasma concentrations after oxytocin treatment. Second, to confirm that secreted PGF $_{2 \alpha}$ is metabolized to PGFM, PGF ${ }_{2 \alpha}$ was administered i.v. in physiological doses to three does: the results revealed the expected rapid rise in PGFM (data not shown). Third, oxytocin treatment results in a threefold rise in the circulating PGFM concentration in red deer (Flint et al., 1994); this result, and the observation of episodic rises in circulating PGFM concentrations during luteolysis in fallow deer Dama dama (Asher et al., 1988) provide further evidence that $\mathrm{PGF}_{2 \alpha}$ is metabolized to PGFM in cervids. Fourth, the fact that negative results were obtained at different times of year, including during the breeding season, suggests that the lack of effect is not an artefact of carrying out the experiment at an inappropriate season. Finally, the presence of oxytocin receptors in the uterus at a concentration sufficient to lead to $\mathrm{PGF}_{2 \alpha}$ synthesis in other ruminants (Sheldrick and Flint, 1985 ) is not inconsistent with the conclusion reached here: changes in the response of the uterus to oxytocin do not always reflect changes in oxytocin receptor concentration (Sheldrick and Flint, 1986), and conditions have been recognized in which receptor concentrations are high, but the $\mathrm{PGF}_{2 \alpha}$ response is absent (Vallet et al., 1990). The failure in response may reflect the absence of an as yet unidentified protein involved in signal transduction or of an enzyme required for prostaglandin synthesis at a later stage of the pathway. 
The authors thank L. Simpson and his staff of rangers at the Forestry Commission, Santon Downham, Brandon, Suffolk, especially R. Whitta. They also thank L. Twardowski, K. Z. Oolyméc and S. Dola of Baranowo and Mragowo, and M. Ingielewicz of the Forestry Centre, Strzałowo, Poland. H. Stanley gave advice on Northern blotting and P. Bartlewski (TEMPUS scholar from the University of Olsztyn in Poland to the Institute of Zoology, London) validated the oxytocin receptor assay for deer tissues; R. Abayasekara and M-J. Searle helped to prepare and measure oxytocin receptors. They also thank Professor G. Schütz (Heidelberg), E. L. R. Sheldrick for laboratory facilities at AFRC Babraham, Cambridge while collecting tissues at Thetford, Z. Marillet, C. Trouvé and N. Guillon at CEBC, for technical assistance, P. Duncan and S. J. G. Hall for help in other ways, and for much kind assistance A. Ziecik (University of Olsztyn) and M. Batten (University of Nottingham). This study was started while A. P. F. Flint was at the Institute of Zoology, Regent's Park, London.

\section{References}

Aitken RJ (1981) Aspects of delayed implantation in the roe deer (Capreolus capreolus) Joumal of Reproduction and Fertility Supplement 29 83-95

Asher GW, Peterson AJ and Watkins WB (1988) Hormonal changes during luteal regression in farmed fallow deer, Dama dama Journal of Reproduction and Fertility 84 379-386

Bischoff TLW (1854) Entwickelungsgeschichte des Rehes. J. Rickers'sche Buchhandlung, Giesen

Chomczynski P and Sacchi N (1987) Single-step method of RNA isolation by acid guanidinium thiocyanate-phenol-chloroform extraction Analytical Biochemistry 162 156-159

Flint APF, Jabbour HN and Loudon ASI (1994) Oxytocin stimulates uterine prostaglandin $\mathrm{F}_{2 a}$ secretion in red deer Cervus elaphus Reproduction, Fertility and Development $6269-271$

Flint APF, Sheldrick EL, McCann TJ and Jones DSC (1990) Luteal oxytocin characteristics and control of synchronous episodes of oxytocin and $\mathrm{PGF}_{2 \mathrm{n}}$ secretion at luteolysis in ruminants Domestic Animal Endocrinology 7 111-124

Flint APF, Sheldrick EL, McCann TJ, Brinklow BR and Loudon ASI (1991) Prostaglandin-induced secretion of oxytocin and prolactin in red (Cervus elaphus) and Père David's (Elaphurus davidianus) deer hinds: evidence for oxytocin of luteal origin General and Comparative Endocrinology 83 432-438

Flint APF, Stewart HJ, Lamming GE and Payne JH (1992) Role of the oxytocin receptor in the choice between cyclicity and gestation in ruminants Journal of Reproduction and Fertility Supplement 45 53-58
Hoffmann B, Barth D and Karg H (1978) Progesterone and estrogen levels in peripheral plasma of the pregnant and non-pregnant roe deer (Capreolus capreolus) Biology of Reproduction 19 931-935

Hooper SB, Watkins WB and Thorburn GD (1986) Oxytocin, oxytocinneurophysin and prostaglandin $F_{2 u}$ concentrations in the utero-ovarian vein of pregnant and non-pregnant sheep Endocrinology 119 2590-2597

Hunter MG, Ayad VJ, Gilbert CL, Southee JA and Wathes DC (1989) Role of prostaglandin $F_{2 q}$ and oxytocin in the regression of $\mathrm{GnRH}$ induced abnormal corpora lutea in anoestrous ewes Joumal of Reproduction and Fertility 85 555-561

Jones DSC and Flint APF (1988) Concentrations of oxytocin neurophysin prohormone mRNA in corpora lutea of sheep during the oestrous cycle and in early pregnancy Joumal of Endocrinology $117409-414$

Kaker ML, Murray RD and Dobson H (1984) Plasma hormone changes in cows during induced or spontaneous calving and the early post-partum period Veterinary Record 115 378-382

Meager A (1987) Quantification of interferons by antiviral assays and their standardization Lymphokines and Interferons: A Practical Approach pp 129-147 Eds MJ Clemens, AG Morris and AJH Gearing. IRL Press, Oxford

Schams D, Barth D and Karg H (1980) LH, FSH and progesterone concentrations in peripheral plasma of the female roe deer (Capreolus capreolus) during the rutting season Journal of Reproduction and Fertility 60 109-114

Sempéré AJ, Mauget R and Chemineau P (1992a) Experimental induction of luteal cyclicity in roe deer (Capreolus capreolus) Journal of Reproduction and Fertility 96 379-384

Sheldrick EL and Flint APF (1981) Circulating concentrations of oxytocin during the oestrous cycle and early pregnancy in sheep Prostaglandins 22 631-636

Sheldrick EL and Flint APF (1983) Luteal concentrations of oxytocin decline during early pregnancy in the ewe Joumal of Reproduction and Fertility 68 $477-480$

Sheldrick EL and Flint APF (1985) Endocrine control of uterine oxytocin receptors in the ewe Joumal of Endocrinology 106 249-258

Sheldrick EL and Flint APF (1986) Transient uterine refractoriness after oxytocin administration in ewes Journal of Reproduction and Fertility 77 523-529

Short RV (1969) Implantation and the maternal recognition of pregnancy Foetal Autonomy (Ciba Federation Symposium) pp 2-26 Eds G Wolstenholme and M O'Connor. Churchili, London

Short RV and Hay MF (1966) Delayed implantation in the roe deer (Capreolus capreolus) Symposia of the Zoological Society of London 15 173-194

Silvia WJ, Lewis GS, McCracken JA, Thatcher WW and Wilson L (1991) Hormonal regulation of uterine secretion of prostaglandin $\mathrm{F}_{2 a}$ during luteolysis in ruminants Biology of Reproduction 45 655-663

Vallet JL, Lamming GE and Batten M (1990) Control of endometrial oxytocin receptor and uterine response to oxytocin by progesterone and oestradiol in the ewe Joumal of Reproduction and Fertility 90 625-634 